\title{
Gastropods in the Intertidal Shore of Kota Kinabalu, Sabah (Malaysian Borneo)
}

\author{
JOHN MADIN*, SUET-MUN HO \& BALU-ALAGAR VENMATHI MARAN \\ Borneo Marine Research Institute, Universiti Malaysia Sabah, 88400 Kota Kinabalu, Sabah, Malaysia \\ *Corresponding author: jonmadin@ums.edu.my \\ Received: 30 April $2021 \quad$ Accepted: 23 June $2021 \quad$ Published: 30 June 2021
}

\begin{abstract}
Intertidal gastropods provide numerous ecological benefits and are responsible for the dynamics of the intertidal shores habitat and their community assemblages. This study examined the community structure of gastropods in the intertidal shore located near the city of Kota Kinabalu, the capital of Sabah where coastal areas are rapidly developed for various purposes and consequently destroying natural habitats. A total of 36 gastropods species from 15 families were recorded. The Planaxis sulcatus was the most abundant species with a density of 480 ind. $\mathrm{m}^{-2}$ followed by Nodilittorina pyramidalis $\left(182\right.$ ind. $\mathrm{m}^{-2}$ ) and Cellana radiata $\left(97\right.$ ind. $\mathrm{m}^{-2}$ ) respectively. The number of species and their abundance, are almost three times lower than the number ever recorded for intertidal shores located in non-urban areas or remote locations. This suggests that the rapidly growing coastal urban areas is threatening the diversity and abundance of intertidal gastropods. The density of gastropod (i.e. P. sulcatus \& N. pyramidalis) was significantly $(\mathrm{p}<0.05)$ high at the lower intertidal shore where slope gradient is steeper with rocks and crevices are the major component of substrates compared to the upper or middle zone which is flatter and composed mainly of coral rubble and sand. Our study suggests that gastropod communities in intertidal shores located adjacent to the urban areas are threatened especially by anthropogenic factors such as frequent human visitations and modification of natural habitat. Future development in the intertidal shore should minimise habitat destruction and should consider infrastructures that encourage gastropod populations to grow and highlighting their ecological role for conservation reasons.
\end{abstract}

Keywords: Borneo, gastropods community, intertidal shore, Kota Kinabalu, Sabah

Copyright: This is an open access article distributed under the terms of the CC-BY-NC-SA (Creative Commons Attribution-NonCommercial-ShareAlike 4.0 International License) which permits unrestricted use, distribution, and reproduction in any medium, for non-commercial purposes, provided the original work of the author(s) is properly cited.

\section{INTRODUCTION}

The gastropod assemblage is an important component of invertebrates in the intertidal shore. They provide a variety of ecological benefits and are responsible for the dynamics of the intertidal ecosystem and its assemblages (Miloslavich et al., 2013). Some examples of their ecological functions include controlling the overgrowth of algae (Thompson et al., 1997; Wai \& William, 2006), provide shells for hermit crabs (Laidre, 2011; Teoh et al., 2014), source of food for other marine fauna as well as parasites, predators and scavengers themselves (Menge, 1983; Boglio \& Lucas, 1997; Ray-Culp et al., 1999).

The intertidal shore habitat is subject to natural abiotic and biotic factors that influence the structure of gastropod community, in particular the list of representing species, their diversity, abundance and distribution along the vertical or horizontal direction of the shores (Crowe et al.,
2000; Beyst et al., 2002; Khanam \& Saher, 2018). Human activities such as manipulation of the intertidal shore for the construction of various infrastructures, recreational areas and tourist attractions (Murray et al., 1999; Crowe et al., 2000), eutrophication of coastal area that induces harmful algal blooms, and the introduction of nonnative species (Carlton, 1996; Ruiz et al., 2000; Savini \& Occhipinti-Ambrogi, 2006) are also known to influence the community structure (Brosnan \& Crumrine, 1994; Thompson et al., 2002).

Sabah (i.e. North Borneo) is one of the states in Malaysia where the surrounding seawater is well known for its mega biodiversity of flora and fauna (Carpenter et al., 2011). However, to the best of our knowledge, information on intertidal gastropods is lacking although their ecological roles is significant and should be conserved. At present, high rates of development of the coastal areas in the state of Sabah was observed, especially 
intertidal zones which are considered to have a high commercial value for tourism activities. For example, in Kota Kinabalu, the capital city of Sabah, development rates are estimated to be more than $20 \%$ per year mainly to meet the demands for the tourism industry (Sabah Tourism, 2002; Jakobsen et al., 2007). Other potential threat includes invasions of alien species (Jackery et al., 2016), sea-level rise and coastal erosion (MohdHanan et al., 2011).

This study examined species composition, abundance, diversity, richness and evenness of gastropods along the vertical zonation (i.e. upper, middle and lower intertidal zones) in relation to slope profile (height/elevation) and substrate types of selected intertidal shores located near Kota Kinabalu city. We anticipate that gastropod communities in the intertidal shores located adjacent to urban areas experienced anthropogenic threats and thus will negatively affect their populations compared to those located in remote locations. This information is imperative to understand the impacts of urbanisation on the gastropod community which is considered as keystone species of intertidal ecosystems (Rittschof \& McClellan-Green, 2005).

\section{MATERIALS AND METHODS}

\section{Study Area}

Three sites of intertidal shore located near the city of Kota Kinabalu were selected (Figure 1). Site 1 $\left(6^{\circ} 2^{\prime} 16.90 " \mathrm{~N} ; \quad 116^{\circ} 6^{\prime} 41.75^{\prime \prime} \mathrm{E}\right)$ and Site 2 $\left(6^{\circ} 2 ' 2.29 " \mathrm{~N} ; 116^{\circ} 6^{\prime} 42.02^{\prime \prime} \mathrm{E}\right)$ are located near Universiti Malaysia Sabah (UMS) and are separated by a sandy beach at a distance of about $1000 \mathrm{~m}$. Another site, referred herein as Site 3 (5'54'3.23"N; $\left.116^{\circ} 2^{\prime} 4.66^{\prime \prime} \mathrm{E}\right)$, is located near Bukit Vor in Putatan sub-district of Kota Kinabalu. All sites are within a radius of less than $7 \mathrm{~km}$ from the city centre and considered a natural intertidal shore. This is in contrast to the intertidal shore located close to the city centre which has been widely developed for various types of infrastructure and subsequently destroying natural habitats of gastropods. The tidal range of Kota Kinabalu varied between $1 \mathrm{~m}$ and $1.5 \mathrm{~m}$ (Malaysia Tide Tables, 2012; 2013).

\section{Field Sampling and Methods}

At each sampling site, three transects (i.e. triplicates) were established perpendicular to the shore using a survey tape starting from the highest watermark to the lowest water level when the water receded. The distance between replicates is about $25 \mathrm{~m}$ but depends on topographic conditions and accessibilities. Three quadrats $(0.5$ $\mathrm{m} \times 0.5 \mathrm{~m}$ ) were placed randomly at every $20 \mathrm{~m}$ transect interval starting from the upper, middle and lower intertidal shores. All live gastropod species found inside the quadrats were identified and counted on the field while the unidentified specimens were taken to the laboratory for identifications. All sampling was done when water is receding to optimize the number of specimens that could be found. However, strong water current and steeper slopes prevent sampling at the lower intertidal shore. A total of three consecutive samplings was done for each sampling sites. All samplings were conducted during spring tide which was on the 14 March 2013, 15 April 2013 and 17 May 2013, respectively (Malaysia Tide Tables, 2013). All specimens were identified to the lowest taxa possible.

The slope profile of the intertidal shore was estimated according to the method of Emery (1961) and Wong (1981) with slight modifications. Measurements were performed using the Auto Level Topcon-AT G6 mounted on a tripod holder and placed on top of a large rock (i.e. a permanent object) at the upper intertidal shore and acts as a reference point. A measuring tape was pulled perpendicular starting from the tripod point until the lowest watermark level. The height of the tripod was recorded and the reading on the staff taken at every $10 \mathrm{~m}$ interval along the transect. The elevation differences between the Auto Levels and staff define the drop of the intertidal slope profile which was then recorded and analysed.

The types and percentage component of the substrate inside the quadrats such as rocks, coral rubble and crevices were estimated at every $20 \mathrm{~m}$ interval of the transect. This was done by taking photographs of the substrate inside the quadrats using a digital camera (Canon G9-3.0). The percentage component of the substrate was estimated based on the total number of occupied grid squares inside the quadrat and finally summing up the total. A fully occupied square grid would give a score of $10 \%$ and the total number of a square box per quadrat is 100 .

\section{Computation and Statistical Analysis}

The average density of individual gastropod was 


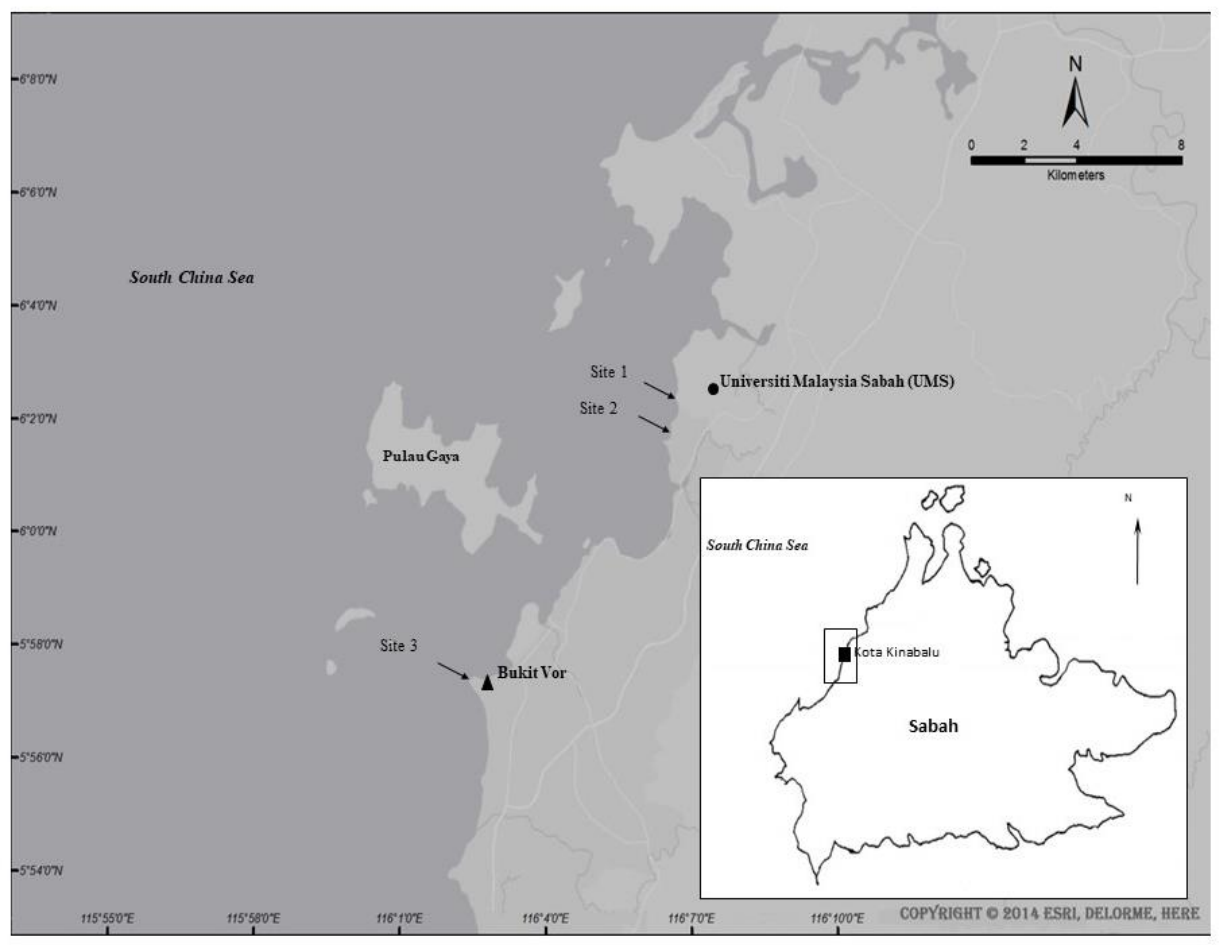

Figure 1. Location of the study site near the city of Kota Kinabalu on the west coast of Sabah (Borneo, Malaysia). Site 1 and Site 2 are located near UMS while Site 3 is located near Bukit Vor

estimated at every $20 \mathrm{~m}$ transect interval as Eq. (1).

Density (ind. $\left.\mathrm{m}^{-2}\right)=\frac{T \times 1 \mathrm{~m}^{2}}{N \times S}$

Where $\mathrm{T}$ is total number of individuals, $\mathrm{N}$ is number of quadrate and $\mathrm{S}$ is Surface area of quadrate.

The ecological indices namely the species richness, Shannon-Wiener diversity index $\left(\mathrm{H}^{\prime}\right)$ and Pielou Evenness index $\left(\mathrm{J}^{\prime}\right)$ were estimated at every $20 \mathrm{~m}$ transect interval.

Computed species density data and the height of intertidal slope were logarithmic $[\log 10(x+1)]$ transformed while the percentage composition of the substrate was arcsin transformed. A ShapiroWilk test was applied to determine the normality and homogeneity of the data and results were not normally distributed, therefore, all further univariate tests were non-parametric. The KruskalWallis $\mathrm{H}$ test using One-way ANOVA was carried out to determine the effect of intertidal zonations (upper, middle and lower) on the density, intertidal height gradient and percentage composition of substrates. The significance level was set at $\mathrm{p}<0.05$. All statistical tests were performed using SPSS for windows version23 software (IBM, Armonk, NY, USA).
The Canonical Correspondence Analysis (CCA) was used to summarise the correlation matrix between the species densities of gastropods, substrate types and slope profile of the intertidal shore. Orloci's chord distances were computed instead of Euclidean distances to avoid the paradox problem associated with the latter when species abundance (density) data were used (Legendre \& Gallagher, 2001). Chord distances were computed via a transformation program downloaded from http://www.bio.umontreal.ca/casgrain/en/labo/tran sformations.html. The program converts a matrix of species density in such a way that the Euclidean distance among rows of the transformed matrix is equal to the chord distance among rows of the original data matrix. The CCA of the average species density was performed using the CANOCO for Windows ver. 4.5.

\section{RESULTS}

\section{Species Composition and Ecological Indices}

A total of 36 species of gastropods from 15 families were recorded (Table 1). The Littorinidae, Muricidae, Neritidae, Cerithiidae and Columbellidae were among the most common families represented by more than three species each. 
Table 1. List of gastropods species and their average density along the upper, middle and lower intertidal zone of Site 1, Site 2 and Site 3, respectively, computed at every $20 \mathrm{~m}$ interval of transects. The total averaged density (i.e. by species and by transect intervals) and ecological indices namely species richness, diversity and evenness as well as the total number of species found in each sites are shown. Species acronyms are given in parentheses.

\begin{tabular}{|c|c|c|c|c|c|c|c|c|c|c|c|c|c|c|}
\hline \multirow[b]{3}{*}{ Depth (m) } & \multicolumn{8}{|c|}{ Site 1} & \multicolumn{3}{|c|}{ Site 2} & \multicolumn{2}{|c|}{ Site 3} & \multirow{3}{*}{ 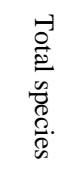 } \\
\hline & \multicolumn{3}{|c|}{$\mathrm{Up}$} & \multicolumn{2}{|c|}{ Mid } & \multicolumn{3}{|c|}{ Low } & \multirow{2}{*}{$\frac{\mathrm{Up}}{0}$} & \multirow{2}{*}{$\frac{\text { Mid }}{20}$} & \multirow{2}{*}{$\frac{\text { Low }}{40}$} & \multirow{2}{*}{$\frac{\mathrm{Up}}{0}$} & \multirow{2}{*}{$\frac{\text { Low }}{20}$} & \\
\hline & 0 & 20 & 40 & 60 & 80 & 100 & 120 & 140 & & & & & & \\
\hline $\begin{array}{l}\text { Angariidae } \\
\text { Angaria delphinus } \\
\text { (Ade) }\end{array}$ & 0 & 0 & 0 & 0 & 0 & 0 & 0 & 0 & 0 & 0 & 1 & 0 & 0 & 1 \\
\hline $\begin{array}{l}\text { Cerithiidae } \\
\text { Clypeomorus }\end{array}$ & & & & & & & & & & & & & & \\
\hline $\begin{array}{l}\text { batillariaeformis (Cba) } \\
\text { Cerithium zonatum }\end{array}$ & 0 & 10 & 11 & 15 & 11 & 6 & 7 & 6 & 0 & 4 & 2 & 0 & 0 & 72 \\
\hline $\begin{array}{l}(\mathrm{Czo}) \\
\text { Cerithium sp. (Csp) }\end{array}$ & $\begin{array}{l}0 \\
0\end{array}$ & $\begin{array}{l}4 \\
2\end{array}$ & $\begin{array}{l}1 \\
3\end{array}$ & $\begin{array}{c}4 \\
17\end{array}$ & $\begin{array}{l}7 \\
6\end{array}$ & $\begin{array}{l}3 \\
0\end{array}$ & $\begin{array}{l}2 \\
2\end{array}$ & $\begin{array}{l}1 \\
0\end{array}$ & $\begin{array}{l}0 \\
0\end{array}$ & $\begin{array}{l}0 \\
0\end{array}$ & $\begin{array}{l}0 \\
0\end{array}$ & $\begin{array}{l}5 \\
5\end{array}$ & $\begin{array}{c}32 \\
0\end{array}$ & $\begin{array}{l}59 \\
35\end{array}$ \\
\hline Columbellidae & & & & & & & & & & & & & & \\
\hline Euplica scripta (Esc) & 0 & 0 & 0 & 0 & 0 & 0 & 0 & 4 & 0 & 0 & 1 & 0 & 0 & 5 \\
\hline $\begin{array}{l}\text { Pictocolumbella } \\
\text { ocellata (Poc) }\end{array}$ & 0 & 0 & 2 & 3 & 4 & 1 & 3 & 0 & 0 & 39 & 13 & 0 & 2 & 67 \\
\hline $\begin{array}{l}\text { Pyrene testudinaria } \\
\text { (Pte) }\end{array}$ & 0 & 0 & 0 & 0 & 0 & 0 & 0 & 1 & 0 & 0 & 2 & 0 & 0 & 3 \\
\hline $\begin{array}{l}\text { Cypraeidae } \\
\text { Monetaria annulus } \\
\text { (Man) }\end{array}$ & 0 & 0 & 0 & 0 & 0 & 0 & 0 & 0 & 0 & 0 & 3 & 0 & 0 & 3 \\
\hline Liotidae & & & & & & & & & & & & & & \\
\hline Liotina peronii (Lpe) & 0 & 0 & 0 & 0 & 1 & 1 & 1 & 0 & 0 & 0 & 0 & 0 & 0 & 3 \\
\hline $\begin{array}{l}\text { Littorinidae } \\
\text { Littoraria articulata } \\
\text { (Lar) }\end{array}$ & 1 & 0 & 0 & 0 & 0 & 0 & 0 & 0 & 1 & 0 & 0 & 0 & 0 & 2 \\
\hline $\begin{array}{l}\text { Littoraria undulata } \\
\text { (Lun) }\end{array}$ & 5 & 0 & 0 & 0 & 0 & 0 & 0 & 0 & 4 & 0 & 0 & 9 & 0 & 18 \\
\hline $\begin{array}{l}\text { Echinolittorina } \\
\text { millegrana }(\mathrm{Nmi}) \\
\text { Nodilittorina }\end{array}$ & 1 & 0 & 0 & 0 & 0 & 0 & 0 & 0 & 0 & 0 & 0 & 0 & 0 & 1 \\
\hline $\begin{array}{l}\text { pyramidalis }(\mathrm{Npy}) \\
\text { Peasiella roepstorffiana }\end{array}$ & 12 & 0 & 0 & 0 & 0 & 0 & 0 & 0 & 6 & 0 & 0 & 62 & 102 & 182 \\
\hline (Pro) & 1 & 0 & 0 & 0 & 0 & 0 & 0 & 0 & 21 & 0 & 0 & 0 & 0 & 22 \\
\hline Lottiidae & & & & & & & & & & & & & & \\
\hline $\begin{array}{l}\text { Lottiidae } \mathrm{sp} . \text { (Lsp) } \\
\text { Patelloida saccharina }\end{array}$ & 5 & 0 & 0 & 0 & 0 & 0 & 0 & 0 & 0 & 8 & 0 & 0 & 64 & 77 \\
\hline (Psa) & 1 & 0 & 0 & 0 & 0 & 0 & 0 & 0 & 0 & 12 & 0 & 0 & 24 & 37 \\
\hline Mitridae & & & & & & & & & & & & & & \\
\hline Mitra decurtata (Mde) & 0 & 0 & 0 & 2 & 0 & 0 & 0 & 0 & 0 & 0 & 0 & 0 & 0 & 2 \\
\hline $\begin{array}{l}\text { Muricidae } \\
\text { Drupella margariticola }\end{array}$ & & & & & & & & & & & & & & \\
\hline $\begin{array}{l}\text { (Dma) } \\
\text { Tenguella granulata }\end{array}$ & 0 & 2 & 6 & 10 & 8 & 4 & 4 & 4 & 0 & 2 & 8 & 0 & 0 & 48 \\
\hline (Tgr) & 1 & 1 & 1 & 1 & 4 & 1 & 5 & 0 & 1 & 6 & 3 & 0 & 8 & 32 \\
\hline Morula musiva (Mmu) & 0 & 0 & 0 & 0 & 1 & 1 & 1 & 0 & 0 & 1 & 1 & 0 & 7 & 12 \\
\hline $\begin{array}{l}\text { Semiricinula sp. (Ssp) } \\
\text { Reishia bitubercularis }\end{array}$ & 0 & 2 & 2 & 5 & 6 & 0 & 0 & 0 & 0 & 7 & 1 & 2 & 2 & 27 \\
\hline (Rbi) & 1 & 0 & 0 & 0 & 0 & 0 & 21 & 0 & 0 & 7 & 8 & 0 & 4 & 37 \\
\hline
\end{tabular}

Note: $\mathrm{Up}=$ Upper, Mid = Middle, Low = lower 
Table 1. Continue.....

\begin{tabular}{|c|c|c|c|c|c|c|c|c|c|c|c|c|c|c|}
\hline \multirow[b]{3}{*}{ Depth (m) } & \multicolumn{8}{|c|}{ Site 1} & \multicolumn{3}{|c|}{ Site 2} & \multicolumn{2}{|c|}{ Site 3} & \multirow{3}{*}{$\begin{array}{l}0 \\
0 \\
0 \\
0 \\
0\end{array}$} \\
\hline & \multicolumn{3}{|c|}{ Up } & \multicolumn{2}{|c|}{ Mid } & \multicolumn{3}{|c|}{ Low } & \multirow{2}{*}{$\frac{\mathrm{Up}}{0}$} & \multirow{2}{*}{$\frac{\text { Mid }}{20}$} & \multirow{2}{*}{$\begin{array}{c}\text { Low } \\
40\end{array}$} & \multirow{2}{*}{$\frac{\mathrm{Up}}{0}$} & \multirow{2}{*}{$\frac{\text { Low }}{20}$} & \\
\hline & 0 & 20 & 40 & 60 & 80 & 100 & 120 & 140 & & & & & & \\
\hline \multicolumn{15}{|l|}{ Neritidae } \\
\hline $\begin{array}{l}\text { Clithon oualaniense } \\
\text { (Cou) }\end{array}$ & 0 & 0 & 0 & 0 & 0 & 0 & 0 & 0 & 0 & 0 & 0 & 2 & 0 & 2 \\
\hline Nerita albicilla $(\mathrm{Nal})$ & 0 & 0 & 0 & 0 & 0 & 0 & 0 & 1 & 0 & 0 & 0 & 0 & 0 & 1 \\
\hline $\begin{array}{l}\text { Nerita chamaeleon } \\
(\mathrm{Nch})\end{array}$ & 0 & 1 & 0 & 0 & 0 & 1 & 0 & 1 & 0 & 0 & 0 & 2 & 3 & 5 \\
\hline $\begin{array}{l}\text { Nerita squamulata } \\
\text { (Nsq) }\end{array}$ & 0 & 0 & 0 & 0 & 0 & 0 & 0 & 0 & 0 & 0 & 0 & 2 & 0 & 2 \\
\hline Nerita litterata (Nli) & 0 & 0 & 0 & 0 & 0 & 0 & 0 & 0 & 0 & 0 & 0 & 1 & 0 & 1 \\
\hline \multicolumn{15}{|l|}{ Nacellidae } \\
\hline Cellana radiata $(\mathrm{Cra})$ & 9 & 0 & 0 & 0 & 0 & 0 & 7 & 0 & 0 & 11 & 1 & 6 & 63 & 97 \\
\hline $\begin{array}{l}\text { Cellana testudinaria } \\
\text { (Cte) }\end{array}$ & 0 & 0 & 0 & 0 & 0 & 0 & 0 & 0 & 0 & 0 & 0 & 0 & 1 & 1 \\
\hline \multicolumn{15}{|l|}{ Planaxidae } \\
\hline Planaxis sulcatus (Psu) & 0 & 0 & 0 & 0 & 0 & 0 & 0 & 0 & 0 & 0 & 0 & 314 & 166 & 480 \\
\hline Supplanaxis niger (Sni) & 3 & 0 & 0 & 0 & 1 & 0 & 0 & 0 & 3 & 0 & 0 & 0 & 0 & 7 \\
\hline \multicolumn{15}{|l|}{ Trochidae } \\
\hline Monodonta labio (Mla) & 0 & 0 & 0 & 0 & 0 & 0 & 0 & 0 & 1 & 0 & 0 & 0 & 0 & 1 \\
\hline $\begin{array}{l}\text { Trochus maculatus } \\
\text { (Tma) }\end{array}$ & 0 & 0 & 0 & 0 & 0 & 0 & 0 & 0 & 0 & 0 & 1 & 0 & 0 & 1 \\
\hline $\begin{array}{l}\text { Chilodontidae } \\
\text { Euchelus atratus (Eat) }\end{array}$ & 0 & 1 & 0 & 0 & 0 & 0 & 0 & 0 & 0 & 0 & 0 & 0 & 0 & 1 \\
\hline \multicolumn{15}{|l|}{ Turbinidae } \\
\hline Lunella cinerea (Lci) & 0 & 0 & 0 & 0 & 1 & 2 & 0 & 1 & 0 & 0 & 0 & 0 & 0 & 4 \\
\hline $\begin{array}{l}\text { Turbo intercostalis } \\
\text { (Tin) }\end{array}$ & 0 & 0 & 0 & 1 & 0 & 0 & 0 & 0 & 0 & 0 & 0 & 0 & 0 & 1 \\
\hline $\begin{array}{l}\text { Total density (by } \\
\text { transect intervals) }\end{array}$ & 40 & 23 & 26 & 58 & 50 & 20 & 53 & 19 & 37 & 97 & 45 & 410 & 478 & - \\
\hline Species Richness & 11 & 8 & 7 & 9 & 11 & 9 & 10 & 8 & 7 & 10 & 13 & 11 & 13 & - \\
\hline Diversity Index (H') & 1.96 & 1.71 & 1.60 & 1.82 & 2.13 & 1.95 & 1.88 & 1.79 & 1.35 & 1.89 & 2.12 & 0.86 & 1.83 & - \\
\hline Evenness Index $\left(J^{\prime}\right)$ & 0.82 & 0.82 & 0.82 & 0.83 & 0.89 & 0.89 & 0.82 & 0.86 & 0.70 & 0.82 & 0.83 & 0.36 & 0.71 & - \\
\hline $\begin{array}{l}\text { Total number of } \\
\text { species (by site) }\end{array}$ & & & & 28 & & & & & & & & & & \\
\hline
\end{tabular}


a. Site 1

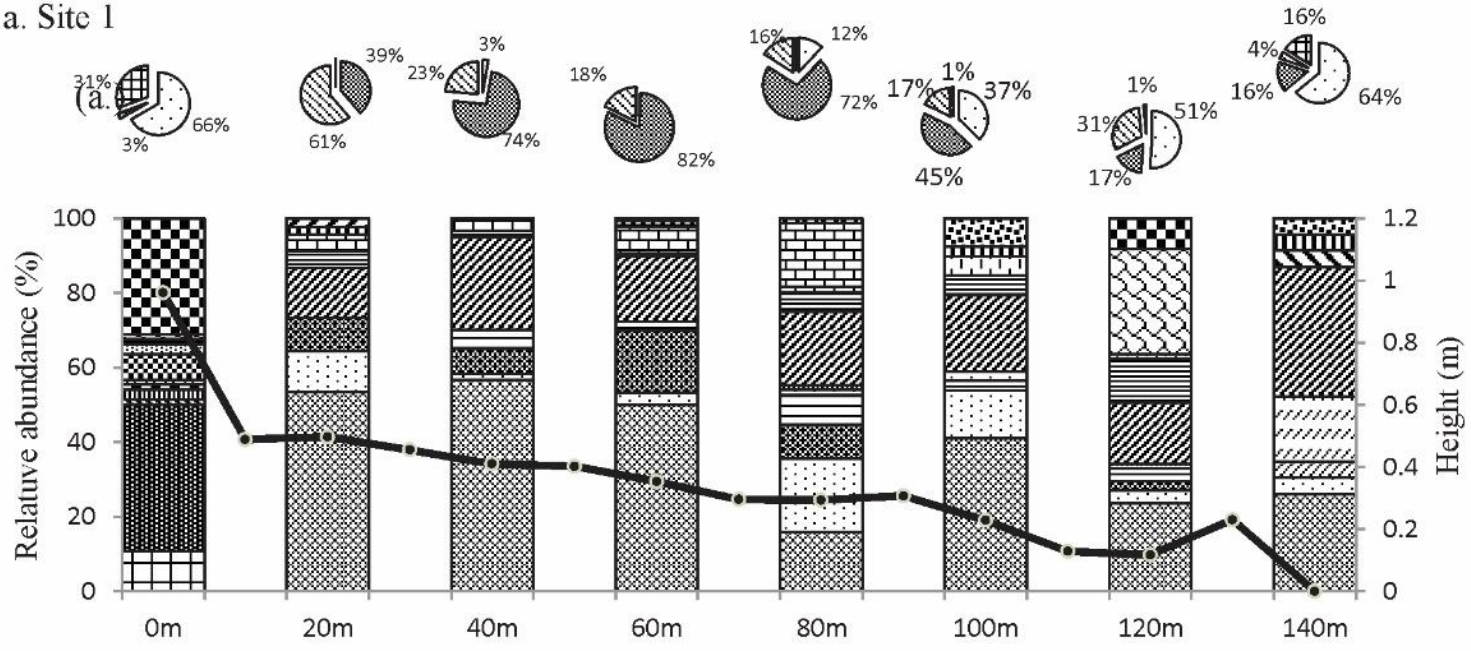

Distance form highest water mark

b. Site 2

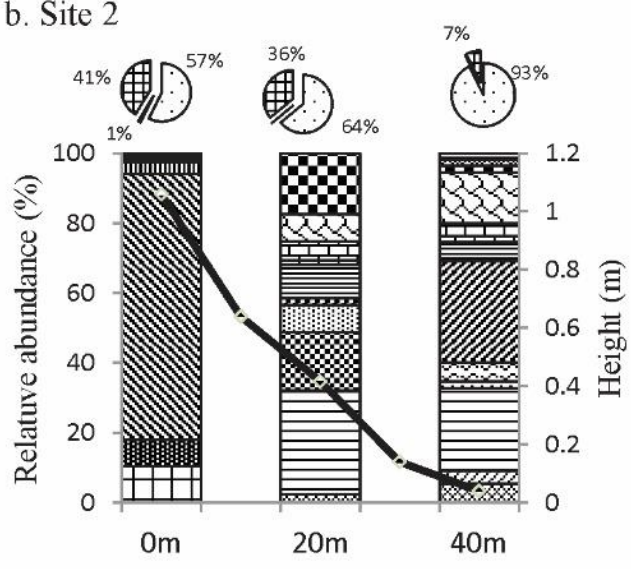

Distance from highest water mark

c. Site 3

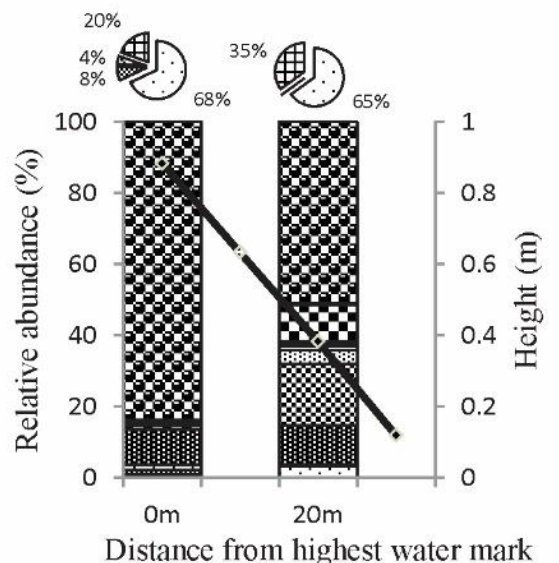

Gastropods species (acronyms)

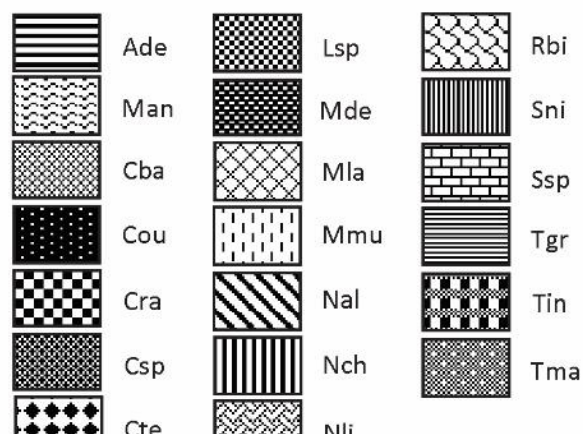

Substrate types

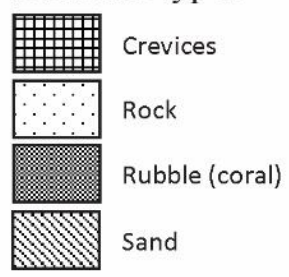

Slope profile /elevation height

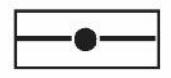

Figure 2. Relative abundance (i.e. percentage) of gastropods along the upper, middle and lower intertidal zone starting from the highest to the lowest watermark level of (a) Site 1, (b) Site 2 and (c) Site 3. The slope profiles (i.e. height $/$ elevation) are indicated in solid line and percentage composition (\%) of substrate types are shown in the pie chart 


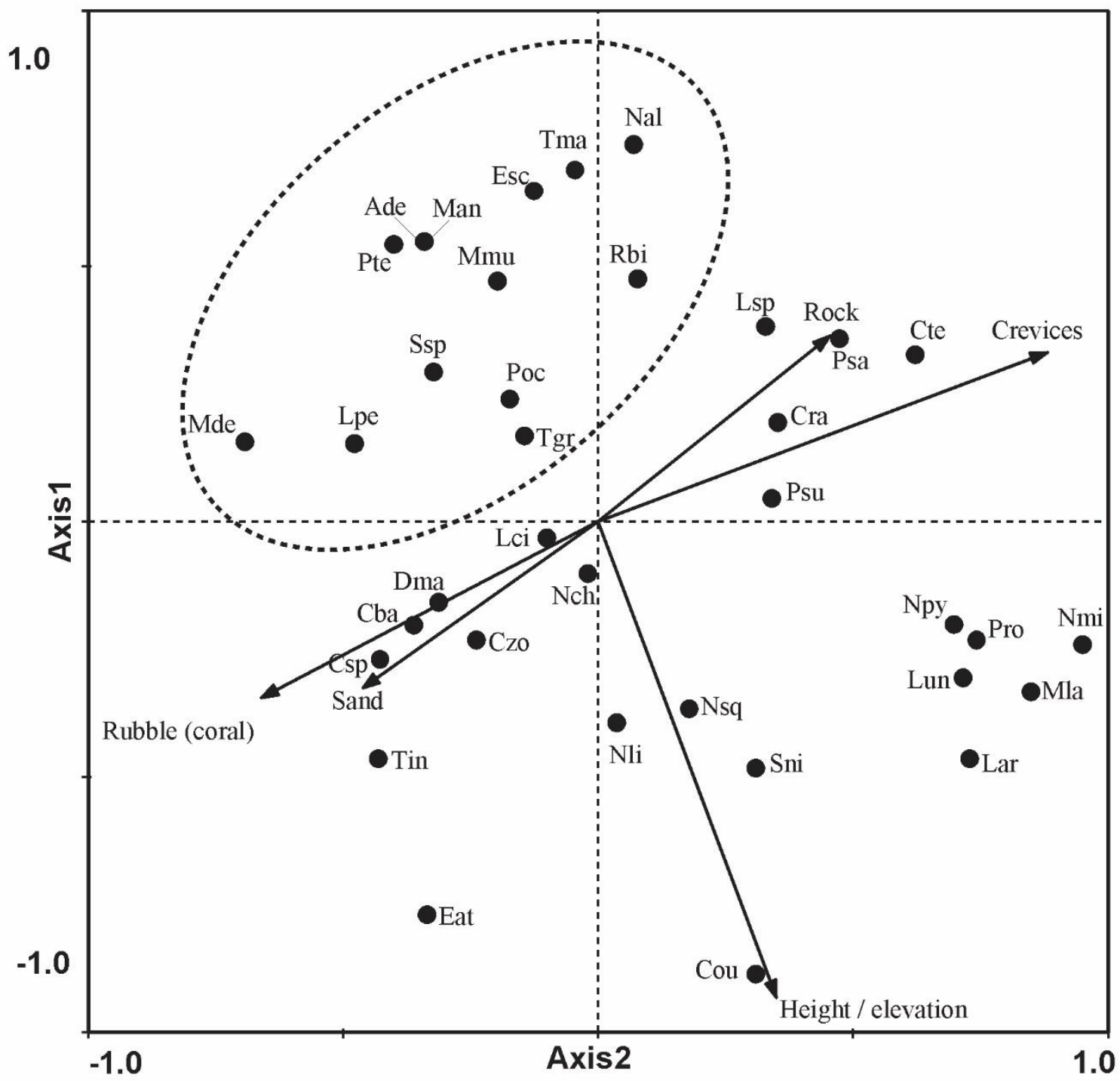

Figure 3. CCA biplot showing the distribution of gastropod species (filled dark circles) with environmental predictors (arrows) namely rubble (coral), sand, rock, crevices and height (elevation) of the intertidal shore. Species that were not preferentially associated with the environment predictor concentrated on the top left-hand side of the diagram (dotted line circle)

The Clypeomorus batillariaeformis, Cerithium zonatum, Pictocolumbella oscillate, Drupella margariticola, Tenguella granulata, Morula musiva and Reishia bitubercularis can be found either in the upper, middle and lower intertidal zones of each study sites. In contrast Angaria delphinus, Monetaria annulus, Clithon oualaniense, $P$. sulcatus and Trochus maculatus found mostly in the lower intertidal zone especially in both Site 2 and Site 3.

The total abundance of gastropod fluctuated throughout the upper, middle and lower zone of intertidal shores (Table 1). In Site 1, it was significantly $(\mathrm{p}<0.05)$ high at the middle $(58$ ind. $\mathrm{m}^{-2}$ ) than at the upper $\left(23\right.$ ind. $\mathrm{m}^{-2}$ ) or lower (19 ind. $\mathrm{m}^{-2}$ ) intertidal zones. Similarly, it was significantly $(\mathrm{p}<0.05)$ high at the middle $\left(97\right.$ ind. $\left.\mathrm{m}^{-2}\right)$ than at the upper $\left(37\right.$ ind. $\mathrm{m}^{-2}$ ) or the lower $\left(45\right.$ ind. $\mathrm{m}^{-2}$ ) intertidal zone of Site 2. However, in Site 3 there was no significant $(p>0.05)$ difference between the upper (410 ind. $\mathrm{m}^{-2}$ ) and the lower (478 ind. $\mathrm{m}^{-2}$ ) intertidal shore.

The species richness along the intertidal shore ranged between $7-13$. The highest was at the lower intertidal zone of both Site 2 and Site 3, however, this was not significantly $(p>0.05)$ 
different to those at the upper or mid-zone. In Site 1 , species richness varied between 7 and 11 .

The highest diversity index (i.e. 2.04) at the middle zone of Site 1 was significantly $(p<0.01)$ high than at the upper (1.71) and lower intertidal zone (1.79). In both Site 2 and Site 3, the diversity index was significantly $(\mathrm{p}<0.05)$ high at the lower zone (i.e. 2.12) compared to the upper intertidal zone. The evenness index $\left(\mathrm{J}^{\prime}\right)$ had a similar pattern to the diversity index, however, there was no significant $(p>0.05)$ difference between the upper, middle and lower intertidal shore for all study sites.

\section{Effect of Beach Slope Profiles and Substrate Types on Gastropod Community}

In Site 1, the height of the intertidal slope decreased significantly $(\mathrm{p}<0.05)$ from $0.96 \mathrm{~m}$ at the upper watermark $(0 \mathrm{~m})$ to $0.48 \mathrm{~m}$ at $10 \mathrm{~m}$ transect interval (Figure 2a). This upper zone mainly consists of rocks $(60 \%) \quad(\mathrm{p}<0.05)$ and crevices $(30 \%)$ substrates. The dominant species were Cellana radiata $(31 \%)$ and $N$. pyramidalis $(39 \%)$ which was significantly $(p<0.01)$ high compared to their abundance at the middle or lower intertidal shore. There was no further significant ( $p>0.05$ ) drop in the gradient height until at $140 \mathrm{~m}$ transect interval whereby coral rubbles $(82 \%)(\mathrm{p}<0.05)$ were the major component of the substrates. This gently sloping intertidal zone is inhabited mainly by $C$. batillariaeformis with a total percentage abundance of nearly $60 \%(\mathrm{p}<0.01)$ compared to its abundance at the lower or upper intertidal shores.

In contrast to the relatively gentle slope of the intertidal shore at Site 1, both Site 2 and Site 3 have a steeper gradients height. In Site 2, the height of the intertidal slope dropped significantly $(\mathrm{p}<0.05)$ from $1.06 \mathrm{~m}$ at the upper watermark (i.e. $0 \mathrm{~m}$ ) to $0.42 \mathrm{~m}$ at the middle (i.e. at $20 \mathrm{~m}$ transect interval), and followed by a drastic drop $(\mathrm{p}<0.05)$ to $0.04 \mathrm{~m}$ height at the lower zone (i.e. at $40 \mathrm{~m}$ transect intervals) (Figure 2b). The main substrate types are rocks (i.e. $>50 \%)$ and crevices ( $>30 \%)$ with a total percentage that was significantly high $(\mathrm{p}<0.05)$ compared to the other substrate types. The dominant species was Peasiella roepstorffiana with a percentage abundance of nearly $80 \%$ $(\mathrm{p}<0.05)$ compared to its abundance in the middle or lower zones. The Pictocolumbella ocellata was more abundant at the middle and lower zone where rocks are the major component of the substrates. The height of intertidal shores at the upper watermark (i.e. $0 \mathrm{~m}$ ) to $0.38 \mathrm{~m}$ at the lower shore (i.e. $20 \mathrm{~m}$ ) (Figure 2c). The major component of substrates are rocks $(63 \%)(\mathrm{p}<0.05)$ and crevices (>30\%) while the dominant species was P. sulcatus with significantly $(\mathrm{p}<0.05)$ high abundance at the upper $(80 \%)$ than at the lower intertidal shore (i.e. $<50 \%)$.

\section{Relationship between Gastropod Community and Environmental Variables}

The canonical correspondence ordination diagram plots the species scores with environmental predictors namely substrate compositions (i.e. coral rubble, sand, rock and crevices) and height (intertidal slope gradient) starting from the lowest watermark of intertidal shore (Figure 3 ). The arrow points to the maximum change in the value of the associated environment variables, while the length is proportional to this maximum rate of change (Ter Braak \& Verdonschot, 1995). The eigenvalues for the first and second axis is 0.598 and 0.320 respectively. The species-environment correlations yielded by these axes were 0.850 and 0.746 with cumulative percentage variances of $53 \%$ and $82 \%$ respectively. This was reinforced by the Monte Carlo test $(\mathrm{f}=6.199, \mathrm{p}=0.002)$ that indicated a significant correlation between environmental variables and the distribution of species abundance. The Monte Carlo test on the overall canonical test also showed statistical significance $(\mathrm{f}=3.056$, $\mathrm{p}=0.002$ ).

A substrate made of sand and rubbles were closely associated, while rocks and crevices fairly associated. Species favouring coral rubbles and sandy substrate were Cerithium sp., $C$. batillariaeformis, D. margariticola, C. zonatum, Lunella cinerea, Nerita chamaeleon and Turbo intercostalis. On the other hand, species favoring rocks and crevices were $P$. sulcatus, Cellana testudinaria, Patelloida saccharina, Lottiidae sp. and $C$. radiata. The $C$. oualaniense, Supplanaxis niger, $N$. squamulata, $N$. litterata and $N$. chamaeleon were closely associated with the height of intertidal shore, preferentially at the upper zone. Species that are not preferentially associated with environment predictors concentrated at the top lefthand side of the diagram. These are $T$. granulata, P. ocellata, Semiricinula sp., M. musiva, Liotina peronii, Mitra decurtata, A. delphinus, M. annulus, Euplica scripta, T. maculatus and Pyrene testudinaria which can be found at the upper, middle and lower intertidal zone of all sites. 


\section{DISCUSSION}

\section{Gastropods in Urban Areas}

Several studies on intertidal shore gastropods in neighbouring areas reported varying numbers of representative species and their abundance. MohdLong et al. (2014) reported at least 33 species of gastropods along the coast of Pulau Sampadi Sarawak (Malaysia) while Marshall et al. (2017) reported 32 species in the intertidal shore of Pulau Punyit Brunei, both of which are comparable to the number of species in this study. In the Grand Island Subic Bay of Philippines, Batomalaque et al. (2010) reported at least 86 species from 24 families while in the Anambas and Natuna archipelagos, Tan and Kastoro (2004) identified 91 species from 24 families but their study also included empty gastropod shells. In Sichang Island, Thailand, Samakraman et al. (2009) found less than 10 species representing at least six families.

The abundance of intertidal gastropods in the present study is relatively low compared to the number ever reported in other intertidal areas located around Borneo Island. For example, the highest density (i.e. 480 ind. $\mathrm{m}^{-2}$ ) of the dominant species such as $P$. sulcatus in the present study is three times lower compared to the density (i.e. 1500 ind. $\mathrm{m}^{-2}$ ) of dominant species namely Littorina pyramidales and Nodilittorina milgrana in Sampadi Island Sarawak as reported in MohdLong et al. (2014). The density of other species such as Clypeomorus spp., Thais kieneri and Lopha spp. were also high in Sampadi Island Sarawak with more than 100 ind. $\mathrm{m}^{-2}$ (Mohd-Long et al., 2014. However, these species were either very few or not found at all during the course of our study.

Several factors may influence the population of intertidal gastropods in particular the number of representing species and their abundance. In this study, a relatively low number of species and abundance may be due to the location of intertidal shores located close to the urban areas and thus are prone to various anthropogenic factors such as human visitations and the modification of the surrounding habitat. High accessibility to human visits threatening the population of intertidal invertebrates (Keough et al., 1993; Roy et al., 2003; Rius et al., 2006) and is particularly responsible for the depletion of species number and abundance of gastropod (Brosnan \& Crumrine, 1994; Huang et al., 2006). Human activities such as walking and overturning of boulders will cause trampling and reduce habitat complexity of marine plant and other macroalgae which serve as shelter as well as food for gastropods (Hayward, 1980; Duffy \& Hay, 1991; Iken, 1999; MolinaMontenegro, 2005; Presscot, 2006; Van De Werfhost \& Pearse, 2007; Istiqlal et al., 2018). This is in contrast to the intertidal shore located far from the urban areas where human visitation is limited and thus can reduce the negative impact on the natural habitat of gastropods (Best et al., 2014; Istiqlal et al., 2018). Indeed, it has been proven that effectively protect intertidal communities from anthropogenic pressures such as human visitation will ultimately maintain existing species biodiversity (Keough et al., 1993; Roy et al., 2003; Rius et al., 2006; Dutton \& Benkendorff, 2008). This further suggests that minimum anthropogenic threats are likely to contribute to high species diversity and abundance of gastropod in remote areas such as in Sampadi Island (MohdLong et al., 2014) and Natuna archipelagos (Tan \& Kastoro, 2004) compared to their population in the urban areas such as in Kota Kinabalu city.

The harvesting of gastropod for food and other uses may also affect the diversity and abundance of intertidal gastropods in the densely populated urban areas of Kota Kinabalu. This could be true since locals were commonly seen collecting gastropods during our sampling. The possible effect of gleaning was particularly obvious on Neritidae where only five species with an average density of fewer than five individuals were found. Neritidae are common in the intertidal shore throughout Malaysian waters (Abbott, 1991; SitiBalkhis et al., 2014) and many species especially the large size individuals are collected for food (Cheng et al., 2012). The gleaning of mostly large size and mature individuals would compromise the reproductive ability and consequently their populations (Duran \& Castilla, 1989; Smith \& Murray, 2005).

Nonetheless, different sampling strategies such as sampling frequencies, size of sampled area and number of replicates also may contribute to the inconsistency of findings among the cited literature. In this study, sampling at the lower intertidal zone of both Site 2 and Site 3 is difficult due to the steeper slope and strong water currents.

\section{Vertical Distribution of Gastropods}

The average slope gradients of the sampled intertidal shores are different, both Site 2 and Site 
3 are steeper compared to Site 1 and this likely influenced the distribution of gastropods along the upper, middle and lower shore. According to Raffaelli and Hawkins (1999), steeper intertidal shore experiences high vertical gradient pressures of abiotic and biotic factors that will decrease from the upper to the lower zone and in turn drive an increase in the invertebrate population at the lower intertidal zone. This is true in both Site 2 and Site 3 where the species richness (i.e. 13), the diversity index (i.e. 2.53) and abundance of gastropod are increasing towards the lowest intertidal zone attributable to the tolerable abiotic stress such as temperature, desiccation, osmotic imbalance and cessation of feeding (Underwood \& Denley, 1984; Peterson, 1991; Bertness et al., 1999; Bagur et al., 2019). On the other hand, gentle sloping of the intertidal shore in Site 1 likely influenced patchiness distributions along the upper, middle and lower shore (Knox, 2001).

Gastropods are likely to have their preferred niche along the upper, middle or lower intertidal shore and this is influenced by the degree of the slope gradients. For example, the dominant species at the upper zones differed among the three sites, in Site 1 it was $N$. pyramidalis and $C$. radiata while in Site 2 and Site 3 it was Peasiella roepstorffiana and Planaxis sulcatus, respectively. In Teluk Aling Malaysia, Nodilittorina sp. and Littoraria sp. were mostly found at the upper intertidal shore (Ahmad et al., 2011) and similarly, E. malaccana was found mostly at the upper intertidal shore of Sichang Island Thailand (Samakraman et al., 2009). This suggests that common species at the upper intertidal shore vary depending on the topographical conditions, geographical location and to some extent anthropogenic factors (Chapman, 1994; Chapman \& Underwood, 1994). Although the upper intertidal species have the adaptations to survive extreme environmental conditions such as desiccation (Sokolova et al., 2000; McMahon, 2001; Khanam \& Saher, 2018), their abundance is usually lower than at the lower intertidal shore. This indicates that human visitation at the upper intertidal shore would cause disturbance to the habitat especially algal cover and other sessile invertebrates which serve as ecosystem buffers for gastropods (Bertness \& Leonard, 1997; Bertness et al., 1999; Bagur et al., 2019). There were very few algae and sessile invertebrates found on the upper intertidal shore of the selected sampling sites in the present study. Species typically found in the middle zone of the intertidal shore were different among each site. In
Site 1 , these were $D$. margariticola, $C$. batillariaeformis and Cerithium sp. while in Site 2 it was the Pictocolumbella ocellata. According to McMahon (2003), gastropods at the middle intertidal zone are subjected to predictable tides and thus preventing extensive desiccations for active foraging activities.

Apart from this, their adaptations for aquatic and semi-aquatic life along with high recruitment rates may allow them for a broader distribution range along the upper, middle and lower intertidal zone (McMahon, 2003). Thus, most of these species can be found in the upper or lower intertidal zone of each sampling sites.

Although the lower intertidal zone was partly inundated by the tide, many species can be found attached to the rocks. These including Clypeomorus batillariaeformis, Euplica scripta and Drupella margariticola in Site 1, Pictocolumbella ocellata, Reishia bitubercularis and $D$. margariticola in site 2 while $P$. sulcatus and C. radiata found mostly in Site 3 . Interestingly, these species were also found at the upper or middle zone, suggesting their wide distribution range attributes to the abilities to adapt to a fully or a semi-aquatic life. According to McMahon (1988; 1990) gastropods at the lower shore are rarely exposed to air and have adaptations associated with purely aquatic life or with some species that may belong to subtidal biotas or the overlap of intertidal and subtidal (Scrosati et al., 2011). Apart from their physiological adaptation, the presence of other organisms as ecosystem buffers also may protects gastropods from predators (Menge \& Lubchenco, 1981; Pinn et al., 2008; Bagur et al., 2019). There were numerous other organisms that can be found at the lower intertidal shore especially in Site 2 and Site 3 and this likely compliment as a habitat and food source for gastropod and certainly contributes to the high abundance.

\section{Substrate Preferences of Gastropods}

The number of gastropod species is more diverse on rocks and inside the crevices compared to other types of substrates. For example, the high composition of rocks (i.e. >60\%), the species richness (i.e. 13) is much high compared to the number found in sandy substrates. Several studies have reported a high number of species on rocky substrates compared to other types of substrates such as sand dominated intertidal shore including 
Beck (1998), Tan and Kastoro (2004), Mohd-Long et al. (2014) and even more species can be found near to the rock bases (Ryu et al., 2012) in particular the large rock ledges (Sutherland, 1990) as was observed in the present study. The suitability of rocks as habitats is primarily attributed to their complexity such as overhangs, crevices and rock pools that provide shelter as well as food for the diverse gastropod species (Beck, 1998; Raffaelli \& Hawkins, 1999). Indeed, species diversity and evenness of intertidal invertebrate's community are positively correlated with habitat complexity (Kassen, 2002; Charles et al., 2011) where the more diverse, complex and persistent habitats are limiting factors for their settlement, recruitments and addition to conspecifics and chemical cues (Lavorel, et al., 1999; Stachowicz, et al., 2002; Charles et al., 2011).

Apart from the effect on species richness, the type of substrates also influences the abundance of gastropods. The density of $C$. zonatum, $N$. pyramidalis, Lottiidae sp., $C$. radiata and $P$. sulcatus were significantly high at the lower intertidal zone where rock is the major component of substrates. Referring to the ordination of species and environmental predictors in Figure 3, the density of these species are strongly associated with rocks and crevices substrate. This shows that both rocks and crevices substrate tends to attract a high abundance of gastropods owing to its complexity and stability of the habitat (Underwood \& Chapman, 1989; Chapman, 1994; Chapman \& Underwood, 1994). Based on field observations, small-sized gastropods tend to hide in narrow crevices especially at the lower bottom of rocks. In contrast to the rocky substratum, coral rubble and sand are lack complexity and stability for gastropods (Batomalaque et al., 2010) as observed. Site 1 wherein coral rubble and sands are the main substrates and appeared to support less abundance of gastropods compared with other sites in this study.

\section{CONCLUSION}

The number of species and abundance of gastropods in the intertidal shore located adjacent to the urban area is substantially low compared to intertidal located in remote areas where anthropogenic activities such as human visitation and modification of surrounding habitat are minimum. The topographical conditions of the intertidal shore determine the distribution pattern along the upper, middle and lower intertidal zone where the steeper the intertidal slope with rocky substrates, species richness and density of gastropods are likely to increase. Future development plan of intertidal shores in urban areas should take into account the factors that encouraged the settlement of gastropod populations and minimise the damage of their natural habitat. More information is needed to understand how habitat alteration would critically affect the populations, meantime conservation efforts should highlight their significant ecological roles.

\section{ACKNOWLEDGEMENTS}

We thank the Borneo Marine Research Institute, Universiti Malaysia Sabah for funding, logistics and research facilities. We are grateful to Muhammad Ali Syed Hussein (Borneo Marine Research Institute, Universiti Malaysia Sabah) and $\mathrm{Su}$ Chunyu (Marine Molluscs Department of National Dong Hwa University, Taiwan) for fieldwork assistance and species identification. This work forms part of a final year project undertaken by the second author.

\section{REFERENCES}

Abbott, R.T. (1991). Seashells of South East Asia. Singapore: Graham Brash (Pte) Ltd.

Ahmad, O., Tay, P.F. \& Yahya, K. (2011). Distribution of intertidal organisms in the shores of Teluk Aling, Pulau Pinang, Malaysia. Publications of the Seto Marine Biological Laboratory, 41: 51-61.

Bagur, M., Gutierrez, J.L., Arribas, L.P. \& Palomo, M.G. (2019). Vacant bivalve boreholes increase invertebrate species richness in a physically harsh, low intertidal platform. Diversity, 11(3): 39.

Batomalaque, G.A., Arce, B.G.P., Hernandez, M.B.M. \& Fontanilla, I.K.C. (2010). Survey and spatial distribution of shoreline malacofauna in Grande Island, Subic Bay. Philippine Journal of Science, 139(2): 149-159.

Beck, M.W. (1998). Comparison of the measurement and effects of habitat structure on gastropods in rocky intertidal and mangrove habitats. Marine Ecology Progress Series, 169: 165-178.

Bertness, M.D. \& Leonard, G.H. (1997). The role of positive interactions in communities: lessons from intertidal habitats. Ecology, 78(7): 1976-1989. 
Bertness, M.D., Leonard, G.H., Levine, J.M., Schmidt, P.R. \& Ingraham, A.O. (1999). Testing the relative contribution of positive and negative interactions in rocky intertidal communities. Ecology, 80(8): 27112726.

Best, R.J., Chaudoin, A.L., Bracken, M.E.S., Graham, M.H. \& Stachowicz, J.J. (2014). Plant-animal diversity relationship in a rocky intertidal system depend on invertebrate body size and algal cover. Ecology, 95(5): 1308-1322.

Boglio, E.G. \& Lucas, J.S. (1997). Impacts of ectoparasitic gastropods on growth, survival, and physiology of juvenile giant clams (Tridacna gigas), including a simulation model of mortality and reduced growth rate. Aquaculture, 150(1-2): 2543.

Brosnan, D.M. \& Crumrine, L.L. (1994). Effects of human trampling on marine rocky shore communities. Journal of Experimental Marine Biology and Ecology, 177(1):79-97.

Carpenter, K.E., Barber, P.H., Crandall, E.D., AblanLagman, M.C.A., Ambariyanto, A., Mahardika, G.N., Manjaji-Matsumoto, B.M., Juinio-Menez, M.A., Santos, M.D., Starger, C.J. \& Toha, A.H.A. (2011). Comparative phylogeography of the Coral Triangle and implications for marine management. Journal of Marine Biology, 2011: 1-14.

Carlton, J.T. (1996). Biological invasions and cryptogenic species. Ecology, 77(6):1653-1655.

Chapman, M.G. \& Underwood, A.J. (1994). Dispersal of the intertidal snail, Nodilittorina pyramidalis in response to the topographic complexity of the substratum. Journal of Experimental Marine Biology and Ecology, 179(2):145-169.

Chapman, M.G. (1994). Small- and broad-scale patterns of distribution of the upper-shore littorinid, Nodilittorina pyramidalis, in New South Wales. Australian Journal of Ecology, 19(1): 83-95.

Charles, J., Appadoo, C. \& Poonyth, A. (2011). A study on assemblage of invertebrates inhabiting rocky shores within the port- limit of Port- Louis, Mauritius. Journal of Coastal Development, 14(2): 159-167.

Cheng, W.H., Yap, C.K., Ismail, A. \& Abdul Rahim, I. (2012). Distribution and concentrations of $\mathrm{Ni}$ in tissues of the gastropod Nerita lineata collected from intertidal areas of Peninsular Malaysia. Pertanika Journal of Tropical Agricultural Science, 35(4): 723-736.
Crowe, T.P., Thompson, R.C., Bray, S. \& Hawkins, S.J. (2000). Impacts of anthropogenic stress on rocky intertidal communities. Journal of Aquatic Ecosystem Stress and Recovery, 7(4): 273-297.

Duffy, J.E. \& Hay, M.E. (1991). Food and shelter as determinants of food choice by an herbivorous marine amphipod. Ecology, 72(4): 1286-1298.

Duran, L.R. \& Castilla, J.C. (1989). Variation and persistence of the middle rocky intertidal community of central Chile, with and without human harvesting. Marine Biology, 103(4): 555-562.

Dutton, A. \& Benkendorff, K. (2008). Biodiversity assessment and monitoring of the Port Stanvac intertidal reef. Report to the Adelaide and Mt Lofty Natural Resource Management Board. Flinders University, Adelaide. Pp 61

Emery, K.O. (1961). A simple method of measuring beach profiles. Limnology and Oceanography, 6(1): 90-93.

Hayward, P.J. (1980). Invertebrate epiphytes of coastal marine algae. In Price, J.H., Irvine, D.E.G. and Farnham, W.F. (eds.) The Shore Environment, Vol. 2: Ecosystems. The Systematics Association Special Volume No. 17b. Academic Press, London. Pp 761787.

Huang, D., Todd, P.A., Chou, L.M., Ang, K.H., Boon, P.Y., Cheng, L. \& Ling, H. (2006). Effects of shore height and visitor pressure on the diversity and distribution of four intertidal taxa at Labrador Beach, Singapore. The Raffles Bulletin of Zoology, 54(2): 477-484.

Iken, K. (1999). Feeding ecology of the Antarctic herbivorous gastropod Laevilacunaria antarctica Martens. Journal of Experimental Marine Biology and Ecology, 236(1): 133-148.

Istiqlal, B.A., Kasa, I.W. \& Yusup, D.S. (2018). Invertebrates diversity of Merta Segara and Nyangnyang Beach: comparison study of two beaches with different characteristics. Journal of Advances in Tropical Biodiversity and Environmental Sciences, 2(2): 14-20.

Jackery, I.L., Madin, J. \& Saleh, E. (2016). Qualitative survey of indigenous, non-indigenous and invasive macrofouling species in Sepangar Bay, Sabah, Malaysia. International Conference on Marine Science and Aquaculture (ICOMSA): Nurturing Innovation Ecosystems for Sustainable Oceans and Societal Wellbeing. 23-24 March 2016. The Magellan Sutera Harbour Resort, Kota Kinabalu, Sabah, Malaysia. 
Jakobsen, F., Hartstein, N., Frachisse, J. \& Golingi, T. (2007). Sabah shoreline management plan (Borneo, Malaysia): ecosystems and pollution. Ocean \& Coastal Management, 50(1): 84-102.

Kassen, R. (2002). The experimental evolution of specialists, generalists, and the maintenance of diversity. Journal of Evolutionary Biology, 15(2): 173-190.

Keough, M.J., Quinn, G.P. \& King, A. (1993). Correlations between human collecting and intertidal mollusc populations on rocky shores. Conservation Biology, 7(2): 378-390.

Khanam, S. \& Saher, N.U. (2018). Zonal diversity and community structure of invertebrate macrofauna in rocky intertidal area of Manora, Karachi, Pakistan. Pakistan Journal of Marine Sciences, 27(2): 93-104.

Knox, G.A. (2001). The ecology of seashores. Florida: CRC Press LLC. Pp 557.

Lavorel, S., Prieur-Richard, A.H. \& Grigulis, K. (1999). Invasibility and diversity of plant communities from patterns to processes. Diversity and Distributions, 5(1/2): 41-49.

Laidre, M.E. (2011). Ecological relations between hermit crabs and their shell-supplying gastropods: constrained consumers. Journal of Experimental Marine Biology and Ecology, 397(1): 65-70.

Legendre, P., \& Gallagher E.D. 2001. Ecologically meaningful transformations for ordination of species data. Oecologia, 129: 271-280.

Malaysia Tide Tables. (2012). Malaysia Tide Tables 2012. Volume 1 and 2. National Hydrographic Centre. Port Klang, Selangor, Malaysia.

Malaysia Tide Tables. (2013). Malaysia Tide Tables 2013. Volume 1 and 2. National Hydrographic Centre. Port Klang, Selangor, Malaysia.

Marshall, D.J., Aminuddin, A. \& P. Hj Ahmad, P.S. (2017). Gastropod diversity at Pulau Punyit and the nearby shoreline - a reflection of Brunei's vulnerable rocky intertidal communities. Scientia Bruneiana, 16(2): 34-40.

McMahon, R.F. (1988). Respiratory response to periodic emergence in intertidal molluscs. American Zoologist, 28(1): 97-114.

McMahon, R.F. (1990). Thermal tolerance, evaporative water loss, air-water oxygen consumption and zonation of intertidal prosobranchs: a new synthesis. Hydrobiologia, 193(1): 241-260.
McMahon, R.F. (2001). Acute thermal tolerance in intertidal gastropods relative to latitude, superfamily, zonation and habitat with special emphasis on the Littorinoidea. Journal of Shellfish Research, 20(1): 459-467.

McMahon, R.F. (2003). Acute hypo- and hypersaline activity responses relative to zonation of intertidal rocky shore and mangrove gastropods from the Burrup Peninsula, Western Australia. In Wells, F.E., Walker, D.I. \& Jones, D.S. (eds.) The Marine Flora and Fauna of Dampier, Western Australia. Perth, Western Australia, Western Australia Museum, Pp 144-146.

Menge, B.A. (1983). Components of predation intensity in the low zone of the New-England rocky intertidal region. Oecologia, 58(2): 141-155.

Menge, B.A. \& Lubchenco, J. (1981). Community organization in temperate and tropical rocky intertidal habitats: prey refuges in relation to consumer pressure gradients. Ecological Monographs, 51(4): 429-450.

Miloslavich, P., Cruz-Motta, J.J., Klein, E., Iken, K., Weinberger, V., Konar, B., Trott, T., Pohle, G., Bigatti, G., Benedetti-Cecchi, L. Shirayama, Y., Mead, A., Palomo, G., Ortiz, M., Gobin, J., Sardi, A., Díaz, J.M., Knowlton, A., Wong, M. \& Peralta, A.C. (2013). Large-scale spatial distribution patterns of gastropod assemblages in rocky shores. PLoS ONE, 8(8): e71396.

Mohd-Long, S., Abg-Abdullah, A.A.F. \& Ab-Rahim, S. A. (2014). Marine gastropod and bivalves of Sampadi Island, Lundu, Sarawak. Monograph Aquatic Science Colloquium 2014. Pp 75-87.

Mohd-Hanan, D.S.M., Anwar, W. \& Aung, T. (2011). Method to estimate the land loss from sea level rise due to gradual warming in Kota Kinabalu, Sabah. Borneo Science, 28(1): 18-28.

Molina-Montenegro, M.A., Munoz, A., Badano, E.I., Morales, B.W., Fuentes, K.M. \& Cavieres, L.A. (2005). Positive associations between macroalgal species in a rocky intertidal zone and their effects on the physiological performance of Ulva lactuca. Marine Ecology Progress Series, 292: 173-180.

Murray, S.N., Denis, T.G., Kido, J.S. \& Smith, J.R. (1999). Human visitation and the frequency and potential effects of collecting on rocky intertidal populations in southern California marine reserves. CalCOFI Report, 40: 100-106.

Peterson, C.H. (1991). Intertidal zonation of marine invertebrates in sand and mud. American Scientist, 79(3): 236-249. 
Pinn, E.H., Thompson, R.C. \& Hawkins, S.J. (2008). Piddocks (Mollusca: Bivalvia: Pholadidae) increase topographical complexity and species diversity in the intertidal. Marine Ecology Progress Series, 355: 173-182.

Presscot, R.C. (2006). An investigation into the impacts of recreational activities of intertidal assemblages at Westward Ho, Devon. Earth \& Environment, 2: 211-252.

Raffaelli, D. \& Hawkins, S. (1999). Intertidal ecology. Netherlands: Kluwer Academic Publishers. Pp 356.

Ray-Culp, M., Davis, M. \& Stoner, A.W. (1999). Predation by xanthid crabs on early post-settlement gastropods: the role of prey size, prey density, and habitat complexity. Journal of Experimental Marine Biology and Ecology, 240(2): 303-321.

Rittschof, D. \& McClellan-Green, P. (2005). Molluscs as multidisciplinary models in environment toxicology. Marine Pollution Bulletin, 50(4): 369373.

Rius, M., Kaehler, S. \& McQuaid, C.D. (2006). The relationship between human exploitation pressure and condition of mussel populations along the south coast of South Africa. South African Journal of Science, 102: 130-136.

Roy, K., Collins, A.G., Becker, B.J., Begovic, E. \& Engle, J.M. (2003). Anthropogenic impacts and historical decline in body size of rocky intertidal gastropods in southern California. Ecology Letters, 6(3): 205-211.

Ruiz, G.M., Fofonoff, P.W., Carlton, J.T., Wonham, M.J. \& Hines, A.H. (2000). Invasion of coastal marine communities in North America: apparent patterns, processes, and biases. Annual Review of Ecology and Systematics, 31: 481-531.

Ryu, S.-H., Jang, K-H., Choi, E-H., Kim, S-K., Song, S-J., Cho, H.-J., Ryu, J-S., Kim, Y-M., Sagong, J., Lee, J-H., Yeo, M-Y., Bahn, S-Y., Kim, H-M., Lee, G-S., Lee, D-H., Choo, Y-S., Pak, J-H., Park, J-S., Ryu, J-S., Khim, J-S. \& Hwang, U-W. (2012). Biodiversity of marine invertebrates on rocky shores of Dokdo, Korea. Zoological Studies, 51(5): 710726.

Sabah Tourism. (2002). Sabah Tourism Report 2000/2001. Report by Sabah Tourism Promotion Corporation. Ruj. JPAS 11.18. Kota Kinabalu, Sabah.

Samakraman, S., Williams, G.A. \& Ganmanee, M. (2009). Spatial and temporal variability of intertidal rocky shore bivalves and gastropods in Sichang
Island, east coast of Thailand. Publication of the Seto Marine Biological Laboratory, 10: 35-46.

Savini, D. \& Occhipinti-Ambrogi, A. (2006). Consumption rates and prey preference of the invasive gastropod Rapana venosain the Northern Adriatic Sea. Helgoland Marine Research, 60(2): 153-159.

Scrosati, R.A., Knox, A.S., Valdivia, N. \& Molis, M. (2011). Species richness and diversity across rocky intertidal elevation gradients in Helgoland: testing predictions from an environmental stress model. Helgoland Marine Research, 65(2): 91-102.

Siti-Balkhis, A.B., Yaman, I.C., Siti-Hasmah, I., Khalil, M.Z., Muhammad-Shukri, M.Y., Zulfigar, Y. \& Aileen-Tan, S.H. (2014). A survey of the marine intertidal macrogastropoda in the northern Straits of Malacca. ASM Science Journal, 8(2): 159-164.

Smith, J.R. \& Murray, S.N. (2005). The effects of experimental bait collection and trampling on a Mytilus californianus mussel bed in southern California. Marine Biology, 147(3): 699-706.

Sokolova, I.M., Granovitch, A.I., Berger, V.J.A. \& Johannesson, K. (2000). Intraspecific physiological variability of the gastropod Littorina saxatilis related to the vertical shore gradient in the White and North Seas. Marine Biology, 137(2): 297-308.

Stachowicz, J.J., Fried, H., Osman, R.W. \& Whitlatch, R.B. (2002). Biodiversity, invasion resistance, and marine ecosystem function: reconciling pattern and process. Ecology, 83(9): 2575-2590.

Sutherland, J.P. (1990). Recruitment regulates demographic variation in a tropical intertidal barnacle. Ecology, 71(3): 955-972.

Tan, K.S. \& Kastoro, W.W. (2004). A small collection of gastropods and bivalves from the Anambas and Natuna Islands, South China Sea. The Raffles Bulletin of Zoology, 11: 47-54.

Teoh, H.W., Syed-Hussein, M.A. \& Chong, V.C. (2014). Influence of habitat heterogeneity on the assemblages and shell use of hermit crabs (Anomura: Diogenidae). Zoological Studies, 53(67): 1-9.

Ter Braak, C.J.F. \& Verdonschot, P. (1995). Canonical correspondence analysis and related multivariate methods in aquatic ecology. Aquatic Sciences, 57: 255-289.

Thompson, R.C., Crowe, T.P. \& Hawkins, S.J. (2002). Rocky intertidal communities: past environmental changes, present status and predictions for the next 
25 years. Environmental Conservation, 29(2): 168-191

Thompson, R.C., Johnson, L.E. \& Hawkins, S.J. (1997). A method for spatial and temporal assessment of gastropod grazing intensity in the field: the use of radula scrapes on wax surfaces. Journal of Experimental Marine Biology and Ecology, 218(1): 63-76.

Underwood, A.J. \& Chapman, M.G. (1989). Experimental analyses of the influences of topography of the substratum on movements and density of an intertidal snail, Littorina unifasciata. Journal of Experimental Marine Biology and Ecology, 134(3): 175-196.

Underwood, A.J. \& Denley. E.J. (1984). Paradigms, explanations and generalizations in models for the structure of intertidal communities on rocky shores. In Strong Jr, D.R., Simberloff, D., Abele, L.G. \& Thistle, A.B. (eds.) Ecological Communities: Conceptual Issues and the Evidence, New Jersey, Princeton University Press. Pp 151-180.
Van De Werfhost, L.C. \& Pearse, J.S. (2007). Trampling in the rocky intertidal of central California: a follow-up study. Bulletin of Marine Science, 81(2): 245-254.

Wai, T.C. \& Williams, G.A. (2006). Monitoring spatiotemporal variation in molluscan grazing pressure in seasonal, tropical rock pools. Marine Biology, 149: 1139-1147.

Wong, P.P. (1981). Beach changes on a monsoon coast, Peninsular Malaysia. Geological Society of Malaysia Bulletin, 14: 59-74. 